\title{
АУТЕНТИЧНОСТ ТЕКСТОВА У НАСТАВИ СРПСКОГ КАО СТРАНОГ ЈЕЗИКА НА ВИШИМ НИВОИМА УЧЕЊА
}

\begin{abstract}
АПСТРАКТ
Веома битан елемент сваког курса страног језика представља уџбеник, а његов неизоставан део, поред најразличитијих типова задатака, чине текстови. Поставља се питање у којој мери ти текстови треба да буду аутентични, као и то да ли је неопходно да се међусобно разликују у погледу врсте, односно типа којем припадају. Циљ овог рада јесте провера валидности изабраних текстова према параметру аутентичности, тј. функционално-стилског домена. У складу са постављеним циљем, регистроваће се постојеће стање у уџбенику за српски језик као страни Научимо српски 2, као и захтеви изнети у релевантној консултованој литератури и Заједничком европском оквиру, на основу чега ће бити извршена анализа корпуса, регистроване доминантне особине и евентуални недостаци. На самом крају hе се дати и предлог корекције, односно допуне текстова у посматраном уџбенику.
\end{abstract}

Кључне речи: српски језик као страни, тип текста, аутентичност, Б2 ниво.

\footnotetext{
${ }^{1}$ Рад је део пројекта Стандардни српски језик: синтаксичка, семантичка и прагматичка истраживања (ОИ 178004), који финансира Министарство просвете, науке и технолошког развоја Републике Србије. Текст рада представља један од сегмената мастерског рада под називом Вештина читања у настави српског језика као страног, писаног под менторством доц. др Јасмине Дражић и одбрањеног у јуну 2015. године на Одсеку за српски језик и лингвистику Филозофског факултета у Новом Саду.
} 


\title{
AUTHENTICITY OF TEXTS USED IN TEACHING SERBIAN AS A FOREIGN LANGUAGE AT HIGHER LEVELS OF LEARNING
}

\begin{abstract}
A very important element of every foreign language course is the textbook and its inevitable part, in addition to the most diverse types of assignments, are texts. The question is to what extent these texts should be authentic, as well as if it is necessary for them to differ in terms of category or type to which they belong. The aim of this paper is to check the validity of chosen texts according to the parameter of authenticity, specifically the domain of functionality and style. In accordance with the set goal, the current state of the textbook for Serbian as a foreign language Let's learn Serbian 2 will be investigated, as well as the requirements set by the relevant literature and the Common European Framework of Reference for Languages, based on which a corpus analysis will be conducted and dominant features and potential deficiencies will be registered. At the end, corrections and additions of the texts in the observed textbook will be suggested.
\end{abstract}

Keywords: Serbian as foreign language, type of text, authenticity, level B2.

\section{1. УВОД}

Предмет овог рада је анализа текстова у уџбенику намењеном учењу српског језика као страног на нивоу Б2, као и представљање до сада истражених потенцијала текста у настави страног језика, али и захтева, оптерећења и исхода које предвиђа Заједнички европски оквир за наведени ниво, а све то у циљу провере валидности изабраних текстова према параметрима као што су тип текста ${ }^{2}$ и аутентичност/неаутентичност (адаптираност).

У складу са постављеним циљем, након упознавања са разматрањима и искуствима домаћих и страних аутора у вези са различитим аспектима употребе и анализе текста у настави страног језика, уследиће регистровање постојећег стања у уџбенику за српски језик као страни и захтева према Заједничком европском оквиру, на основу чега ће бити извршена анализа корпуса, регистроване доминантне особине и недостаци, а затим дат и предлог корекције.

2 Под типом текста подразумева се тематска разнородност, припадност одређеном функционалном стилу/подстилу или књижевном жанру. 
Корпус за анализу чини уџбеник Научимо српски $2^{3}$, тачније лекције 6-10 које су предвиђене за обраду на Б2 нивоу, чија ће се валидност и прикладност упоредити са захтевима у Заједничком европском оквиру за живе језике. Осим тога, као секундарни корпус коришћени су текстови различитих типова који служе као смерница за увођење аутентичних писаних форми у постојеће тематске целине (речници, публицистички текстови, есеји, упутства, итд.).

\section{2. РАНИЈА РАЗМАТРАҢА}

У чланку Teaching reading ${ }^{4}$ првенствено се говори о разлици између традиционалног и савременог приступа у погледу избора текстова који се користе у настави страног језика. У традиционалној настави материјали за читање бирани су из текстова који репрезентују „више” облике културе, што значи да је читање аутентичних материјала ограничено на дела великих аутора и резервисано за студенте (ученике) на вишим нивоима, који су достигли ниво језичких вештина потребан за њихово разумевање. Комуникативни приступ учењу језика нуди различите улоге читања у учионици и типове текста који се могу користити. ${ }^{5}$

Јелена Марковић у раду Екстензивно читање у настави страних језика наводи разлике између интензивног и екстензивног читања и као битне карактеристике екстензивног читања издваја: велику количину прочитаног материјала, разноврсност материјала који се чита, издања различита по теми и жанру. Ауторка расправља и о питању аутентичности текстова који се користе у настави страног језика. Док одређен број аутора сматра да само аутентични језик води квалитетном учењу страног језика, други то не прихватају. У вези са тим, дефинишу се појмови аутентичан,

\footnotetext{
${ }^{3}$ Уџбеник Научимо српски 2 (Let's learn Serbian 2) дело је групе професора са Одсека за српски језик и лингвистику Филозофског факултета у Новом Саду (М. Алановић, И. Бјелаковић, Н. Бугарски, Ј. Дражић, М. Курешевић, Ј. Војновић) и настао је као резултат искустава у раду у оквиру Летње школе српског језика, историје и културе и Центра за српски језик као страни. Прво издање уџбеника изашло је из штампе 2007. године, а прате га радна свеска и цеде ромови са озвученим вежбама слушања.

${ }^{4}$ Чланак је доступан на: http://www.nclrc.org/essentials/reading/reindex.htm. Датум приступа 15. 6. 2017.

5 Када је циљ стицање комуникативне компетенције, свакодневни материјали попут распореда на железници, новинских чланака и веб-сајтова из области путовања и туризма постају прикладан материјал за учење, јер је читање оваквих материјала начин на који је могуће стећи знања и вештине потребне савременом кориснику. Упутства за читање и увежбавање читања тако постају суштински делови наставе језика на свим нивоима.
} 
оригиналан и упрошћен, те се аутентичним сматра текст који успешно служи комуникацији и раздваја се од појма оригиналности - особине текста на коју читалац не може да утиче. Изменом оригиналног настаје упрошћен текст. Упрошћавање треба вршити тако да се смањи количина информација из оригиналног текста, а тако добијен текст је углавном аутентичан јер пружа читаоцу количину информација коју он може да прими и разуме. С тим у вези, ауторка наводи теорију Видоусона да се упрошћавањем текста могу добити просте приче (упрошћавањем садржаја и структуре текста) и упрошћене верзије (упрошћавање структуре уз задржавање садржаја), па је боље користити просте приче јер задржавају аутентичност (Marković 2005: 91-97).

Данијела Ђоровић, између осталог, разматра специфичност вештине читања у настави језика струке и даје примере конкретних наставних активности које се могу користити и у стицању вештине читања и разумевања текста у настави на вишим нивоима попут Б2. Ауторка скреће пажњу на разлику између читања у стандардној настави страног језика и за потребе струке (постојање специфичне сврхе за коју се чита), те у вези са тим наводи задатке који се постављају пред читаоца стручног текста, као и основне стратегије и технике у које спадају: предикација, критичко читање, извлачење закључака, откривање значења непознатих речи дедуктивним путем, летимично читање (енг. skimming), читање на прескок (енг. scanning), читање у циљу поимања целокупног текста, раздвајање одређених чињеница од осталих информација, разумевање нелинеарних графичких елемената, разумевање текстуалне организације и језичко-семантичких аспеката текста, уочавање унутрашње повезаности делова текста, запажање маркера дискурса и њихове функције у тексту. Приликом читања на страном језику може доћи до интерференција из матерњег језика, па је за разумевање неопходна граматичка и лексичка база, као и препознавање структуре текста, правилан избор и градација текстова. Инсистира се на развијању когнитивних и метакогнитивних способности које се активирају и у читању на матерњем језику, само што их студенти често нису свесни. У зависности од дисциплине и врсте текста, жанрови и регистри се мењају. Вештина читања за потребе струке назива се и „вештина читања садржаја” јер се читање увежбава као процес проналажења, издвајања и организовања података у виду белешки, резимеа, мапа текста и сл. (Ђоровић 2011: 811836). 
Сава Анђелковић и Ана Миловановић презентују савремене, креативне и ефикасне начине коришћења текста у оквиру наставе српског језика као страног, који помажу приликом стицања вештине читања и разумевања. Ана Миловановић представља луткарску методу коју је користила у раду на Софијском универзитету „Свети Климент Охридски”.

„При избору текстова за студентске представе водило се рачуна не само о критеријуму уметничке вредности текста, већ и о критеријуму узрасних интересовања студената, као и о њиховом интелектуалном и културном нивоу. Рад на представи подразумевао је смисаону и естетску анализу драмског текста и упознавање [...] социокултурног миљеа из кога је текст поникао" (Миловановић 2007: 94).

Анђелковић ${ }^{6}$ посебно обраћа пажњу на учење текста за сцену и резултате у савладавању српског као страног језика. Усвајање текста аутор изједначава са усвајањем језика и истиче: „Када студенти науче напамет текстове песама или једног комада који траје сат и по или два сата, извесно је да је и њихово свеукупно владање језиком много боље" (Анђелковић 2011: 339). Памћење са емоционалном конотацијом омогућује брже усвајање текста, а ономе ко учи језик пружа сигурност приликом конструкције нових реченица у говорном језику. Овакав приступ тексту могућ је само на врло ограниченој грађи - драмски текстови и они који се могу драматизовати.

У оквиру књиге Discussions that work предлаже се употреба писама која се односе на савете, увреде, комплименте, жалбе, лечење, заправо на све оно што захтева реакцију примаоца. Занимљива је и активност која подразумева комбиновање верзија - два ученика добијају две различите верзије истог текста, обе са грешкама у виду нелогичности, потребно је да направе праву верзију приче а након тога следи упоређивање и дискусија (Ur 1997: 90-98). Неке од активности које предлаже Скривенер јесу читање чланака у новинама, музејског летка, огласа или туристичких понуда, након чега следе дискусије. Употребом свега наведеног читање се повезује са говорењем на начин који је сличан ситуацијама у реалном животу (Scrivener 2005: 31-186).

\footnotetext{
${ }^{6}$ Наведени аутор преноси искуство стечено у раду Атеље театра на српскохрватском језику на Катедри за славистику Универзитета Париз IV - Сорбона, где се повезују часови из наставе књижевности са извођачким искуством студената. Разматрају се предавања са часова књижевности који подразумевају тумачење текстова и рад на њима приликом припреме представа за сценско извођење, што одступа од традиционалног приступа.
} 


\section{3. ТИП ТЕКСТА И АУТЕНТИЧНОСТ У ЗАЈЕДНИЧКОМ ЕВРОПСКОМ ОКВИРУ}

На нивоу Б2 требало би да кандидат (ученик/студент) може да чита чланке и извештаје о савременим питањима о којима аутор има посебан став или сопствено гледиште, као и да разуме књиге савремених прозних писаца (3ЕО 2003: 35). Што се разумевања кореспонденције тиче, предвиђено је да кандидат „може да чита уобичајену кореспонденцију из свог подручја и да схвати смисао и значење” (3ЕО 2003: 83). Док чита ради усмеравања, предвиђа се да је кандидат у стању да пређе сложен и дужи текст, уочавајући најважније делове. Требало би, такође, да брзо одреди садржај и значај неке информације у новинском чланку или репортажи, у широком опсегу стручних тема (ЗЕО 2003: 83). Ако чита ради информисања и вођења расправе, потребно је да буде у стању да „разуме чланке и извештаје о савременим проблемима друштва у којима аутори износе лични став или посебно гледиште". За кандидата који је достигао ниво Б2+ сматра се да „може да користи обавештења, идеје и размишљања из веома стручних текстова у свом подручју деловања, али и да разуме специјализоване публикације изван свог подручја, уз повремено коришћење речника ради провере разумевања" (ЗЕО 2003: 84). Уз то, кандидат треба да буде у стању да „разуме дужа и сложена упутства са тематиком из своје области, укључујући и детаље који се односе на услове одржавања и примене, под условом да може поново да ишчита теже делове" (ЗЕО 2003: 84).

Што се писаних текстова тиче, у Заједничком европском оквиру као врсте и типови наводе се: књиге, литерарне ревије, романи, часописи, дневне новине, рецепти, уџбеници, стрипови, брошуре, проспекти, каталози, рекламни материјали, натписи, плакати, етикете на производима у продавницама и на амбалажи, улазнице, формулари и упитници, речници и тезауруси, пословна и стручна писма, факсови, лична писма, вежбе и писмени састави, службена упутства, извештаји, белешке и поруке, базе података (ЗЕО 2003: 109). Када се посматра екстерни контекст употребе језика, текстови се могу класификовати на оне који припадају приватној (телетекст, гаранције, рецепти, уџбеници, књиге, часописи, новине, рекламне публикације, брошуре, приватна пошта, преснимавања, радиоемисије), јавној (јавна саопштења, етикете, амбалаже, проспекти, графити, улазнице, ред вожње и сатница, огласи, обрачуни, програми, уговори, јеловници, свете књиге, заклетве, химне), стручној (пословна писма, фусноте из извештаја, упутства у случају опасности, упутства за употребу, 
обрачуни, рекламни материјали, етикете и амбалажа, описи послова, визиткарте) и образовној сфери (изворна документа, школски уџбеници, школска лектира, стручна литература, писање на табли, разне белешке, текстови на екрану компјутера, видеотекст, вежбанке, чланци из новина, речници) (ЗЕО 2003: 61).

Када је у питању врста текста, познавање жанра и домена помаже ученику да разуме и предвиди структуру и садржај текста. Битно је и то да ли се ради о конкретној или апстрактној тематици текста - конкретан опис, инструкција или нарација вероватно ће бити мање захтевни од апстрактне аргументације и објашњења. Јако важан проблем јесте и то у којој мери текстови који се презентују ученицима треба да буду аутентични. Могу се појавити аутентични текстови, тј. припремљени у комуникативне сврхе без намере да се користе у настави језика. Пример за то су необрађени аутентични текстови с којима се ученик сусреће током директног искуства у употреби језика (дневне новине, часописи, ТВ преноси) или аутентични текстови изабрани, адаптирани и/или прерађени тако да буду у складу са учениковим искуством, интересовањима и карактеристикама. Друга могућност су текстови посебно писани за коришћење у настави језика, који су написани тако да пружају контекстуализоване примере лингвистичког садржаја који треба обрадити (нпр. у одређеној наставној јединици) или изоловане реченице за коришћење у вежбама (ЗЕО 2003: 159-160).

\section{4. ТЕКСТОВИ У УЏБЕНИКУ НАУЧИМО СРПСКИ 2 И ПРЕДЛОЗИ ДОПУНЕ}

\section{1. Анализа постојећих текстова у уџбенику}

За обраду на нивоу Б2 предвиђен је други део ове књиге, односно лекције од шесте до десете. У шестој лекцији која носи назив Гастрономија појављују се два текста за читање и разумевање: $У$ једном новосадском ресторану и Медищина или надрилекари. Седма лекција носи назив $У$ здравом телу здрав дух (yx!) и садржи текстове $У$ продавници спортске опреме и Криви и организатори и навијачи. Наслов осме лекције је Ако... онда и у оквиру ње имамо текст У потрази за послом. Тема девете лекције је Путовања и ту се појављују два текста: Поздрав са Копаоника и Добро дрво. Текст Коса припада последњој, десетој лекцији под насловом Празници, обичаји, веровања. У наставку рада укратко ће бити представљени резултати анализе наведених текстова када се ради о типу текста и његовој аутентичности. 
Текст 1 - У једном новосадском ресторану ${ }^{7}$. Текст је написан у форми дијалога, представља свакодневну ситуацију и може се сврстати у приватну сферу. Што се степена аутентичности тиче, текст је у потпуности конструисан с циљем да се користи у настави страног језика у оквиру одређене лекције.

Текст 2 - Медицина или надрилекари ${ }^{8}$. Текст је комбинација нарације и дијалога. Описује ситуацију у чекаоници лекарске ординације и разговор који се одвија том приликом, па се може сврстати у приватну, али и јавну сферу. Ако се посматра према критеријуму аутентичности, текст је потпуно конструисан, намењен за коришћење у оквиру одређене лекције.

Текст 3 - У продавници спортске опреме9. Текст је комбинација нарације (уводни део) и дијалога. Презентује ситуацију у продавници спортске опреме, тачније куповину кошаркашке опреме. Може се сврстати у приватну, али и стручну сферу (спорт). Што се аутентичности тиче, ради се о потпуно конструисаном тексту, намењеном за учење страног језика и обраду у оквиру одређене лекције (тематске целине).

Текст 4 - Криви и организатори и навијачи ${ }^{10}$. Ради се о тексту наративног типа (за разлику од претходна три), у облику новинског извештаја о инциденту на кошаркашкој утакмици. Пошто је реч о тексту информативног карактера који се појављује у медијима, припада јавној сфери. У погледу аутентичности, реч је о адаптираном тексту (аутентичан текст прерађен тако да одговара циљевима лекције), што га такође издваја у односу на претходна три који су били потпуно конструисани. Већа је вероватноћа да се ради о простој причи него о упрошћеној верзији (и структура и садржај су прилагођени потребама одређене лекције и нивоу знања студената). Читањем овог текста студенти се оспособљавају за читање чланака и извештаја о савременим питањима, као и за то да одреде садржај и значај неке информације у новинском чланку.

Текст 5 - У потрази за послом ${ }^{11}$. Текст је у форми дијалога, али му претходи текст огласа за посао (који је уједно и део основног текста и текст који служи као мотивација и увод у тему). Стога, може се рећи да припада приватној (транскрипт дијалога), а у исто време и јавној сфери (оглас). Са аспекта аутентичности, оглас је аутентичан текст преузет из новина, а

\footnotetext{
${ }^{7}$ Текст се налази у уџбенику Научимо српски 2 на 74. и 75. страни.

${ }^{8}$ Текст се налази у уџбенику Научимо српски 2 на 82. и 83. страни.

${ }^{9}$ Текст се налази у уџбенику Научимо српски 2 на 88. страни.

${ }^{10}$ Текст се налази у уџбенику Научимо српски 2 на 91. страни.

${ }^{11}$ Текст се налази у уџбенику Научимо српски 2 на 102. страни.
} 
дијалог потпуно конструисан како би се користио у оквиру одређене лекције.

Текст 6 - Поздрав са Копаоника ${ }^{12}$. Текст је у форми писма, односно разгледнице. Може се сврстати у приватну сферу. Када се посматра аутентичност, ради се о конструисаном тексту, али написаном по угледу на аутентичан.

Текст 7 - Добро дрво ${ }^{13}$. У питању је прозни текст, прича Шела Силверстејна. Будући да садржи важне поуке о животу, може се сврстати у образовну сферу. Ради се о аутентичном (преведеном) тексту. Док читају овај текст, студенти развијају компетенцију разумевања књига/прича савремених прозних писаца, као и проблема друштва о којима аутор износи став (директно или индиректно).

Текст 8 - Коса ${ }^{14}$. У питању је текст у форми одреднице из енциклопедије или чланка из научно-популарног часописа, може се сврстати у образовну сферу. Реч је о аутентичном тексту који је у минималној мери прерађен како би се прилагодио потребама лекције и нивоу знања студената (тешко је са сигурношћу утврдити да ли се ради о простој причи или упрошћеној верзији).

Оно што евентуално недостаје су текстови који би пружили могућности оспособљавања за: читање и разумевање упутства, разумевање информативних емисија и телевизијских серија, документарних филмова, интервјуа, расправа, филмова (српски превод, записи), прављење резимеа новинских текстова, разговора, документарних филмова и резимеа неког филма или позоришне представе - произвођење текстова. Такође, не пружа се прилика за коришћење обавештења, идеја и размишљања из веома стручних текстова у сопственом подручју приликом читања ради информисања и вођења расправе (предвиђено за Б2+ ниво). У складу са тим, у наредном пододељку предлаже се неколико текстова уз помоћ којих би се надоместили неки од утврђених недостатака.

\footnotetext{
${ }^{12}$ Текст се налази у уџбенику Научимо српски 2 на 111. страни.

13 Текст се налази у уџбенику Научимо српски 2 на 118. страни.

${ }^{14}$ Текст се налази у уџбенику Научимо српски 2 на 123. страни.
} 


\section{2. Предлог допуне ${ }^{15}$}

Пунији ефекат био би постигнут уколико би се у уџбеник уврстили пасажи аутентичних текстова. Надаље се наводе изабрани текстови и кратки описи могућности њихове употребе, с циљем да се у оквиру курса студентима приближе српска дневна штампа, књижевност и стручна литература, али и да се студенти оспособе за разумевање текстова попут упутстава и рецепата са којима се сусрећу у свакодневном животу.

Прилог 1 - Јован Дучић: „Благо цара Радована” (одломак). Текст припада књижевно-уметничком стилу. Одабран је одломак есеја $O$ пријатељству, део у којем аутор износи свој лични став. У питању је уметнички текст домаћег аутора, који недостаје у уџбенику. Уклапа се у 9. лекцију, као замена или допуна тексту Добро дрво, који такође говори о пријатељству. Пружа подстицај за екстензивно читање. Погодан је за уочавање личног става аутора о некој теми. Може послужити за поређење са текстом Добро дрво, на основу тога како различити аутори описују пријатељство.

(...) Не треба пријатеља ценити по правди, него по срцу. Чим вас неко суди по правди, он је мањи ваш пријатељ него ваш прикривени непријатељ. Човека најискреније волимо кад га волимо заједно са његовим недостацима, чак кад га волимо баш због његових недостатака. Не воли се савршенство у човеку него у Богу; у човеку се воли само свој сопствени дух и своја сопствена природа. Зато је пријатељство мрачно и нерасудно, као и љубав; а љубав је извесно мрачнија и нерасуднија него и сама мржња. Ко пријатеља тумачи и анализира, тај га не воли. Свакако, не верујем да ће нас неко волети зато што смо бољи од њега. Само човек без љубави измислио је ону познату реч да треба волети већма истину него пријатеља Платона, иако се ова изрека приписује Аристотелу. Ја мислим, напротив, да треба више волети пријатеља Платона него и истину. Срећом што се тако и догађа у свим пријатељствима великог стила. Уосталом, ипак се на свету више живи на основи пријатељства него на основи појединих истина. ${ }^{16}$

Прилог 2 - одредница из Речника САНУ ${ }^{17}$. Текст припада научном стилу, у питању је одредница из речника. Уклапа се у последњу лекцију Празници, обичаји, веровања и представља добар материјал за допуну текста

\footnotetext{
15 Сви текстови су пренети у изворном облику, без корекција у погледу стила, граматике и правописа. На тај начин они који српски језик уче као страни јачају своју језичку компетенцију, оспособљавају се да уоче и исправе грешку.

${ }^{16}$ Цео извод који се сматра примереним налази се у мастерском раду, а овде је дат само један његов део.

${ }^{17}$ Одредница се односи на лексему коса.
} 
Kоса јер говори о коси, као и различитим веровањима у српском народу везаним за њу. Помаже да се студенти упознају са структуром речника.

коса $^{1}$ ж 1. (у јд. и мн. , у зб. значењу) а. длаке на глави, власи.

фиг. глава, личност. б. длаке, маље на кожи, на крзну животиња. в. Влакнасти израштаји на епидерми биљака, влакна, нити. г. покр. најдужа и најлепша пера петлова репа.

2. покр. везивно ткиво између мишића и костију, жила, тетива. -

3. покр. а. Намотана пређа, оснутак; повесмо. б. врста веза налик на плетеницу, кику

4. бот. а. боровница б. покр. нека врста траве са два дужа и два краћа прашника (Банат, Ђер.). ${ }^{18}$

Прилог 3 - чланак из Асоцијативног речника ${ }^{19}$. Текст припада научном стилу, заступљен је културолошки, ментални план језика. Истраживање је спроведено по принципу стимулус-реакција (од сваког испитаника се очекивало да наведе реч која му прва падне на памет и то само једну реч). Није пренета комплетна одредница, одабрано је првих двадесет асоцијација (према учесталости) на реч коса. Текст се уклапа у последњу лекцију (текст: Коса, тема: Празници, обичаји, веровања). Може послужити за поређење са речничком одредницом, уочавање разлика у погледу садржаја и структуре. Студентима би се пружила могућност да упореде савремено виђење овог појма са традиционалним (речник САНУ издат је 1978, а истраживање чији се резултати овде презентују 2005. године).

\section{KOCA}

дуга 92; плава 39; глава 37; црна 35; длака 32; бујна 30; фризура 19; влас 18; филм, плаво 15; фризер, лепота, трава 14; реп 12; чешаљ, дугачка 10; бујност, црно, фарба 9; плавуша, шампон, шнала 8; лепа 7; црта, длаке, украс, жена 6; дужина, густа, кратка, на глави, равна, смеђа, смрт 5; девојка, хипици, коврџава, коврџе, меко, права, тамна, власи 4; боја, црвена, гумица, кика, кикице, коса, коврџа, локна, мирис, мјузикл, пегла, плетеница, равно, сјај, шишање 3 (...).

Прилог 4 - Упутство за лек Diprosalic. Ради се о типичном упутству, а то је управо оно што недостаје у уџбенику. Уклапа се у прву

\footnotetext{
18 Предвиђен је читав речнички чланак, са примерима и потврдама, али су за ову прилику издвојена само значења.

${ }^{19}$ У питању је асоцијација на реч коса.
} 
лекцију, тачније њен други део који је везан за медицину - здравље и болести. Одабран је део текста који се односи на употребу лека. На тај начин се студенти оспособљавају за читање и разумевање упутства. Ако се посматра лексика, појављују се стручни медицински/фармацеутски термини, али су у питању интернационални називи па их страни студенти могу разумети.

\section{3. КАКО СЕ УПОТРЕБЉАВА ЛЕК DIPROSALIC}

Одрасли: Једном до два пута дневно. У већини случајева треба нанети танак слој на оболелу област и нежно утрљати два пута дневно. [...] Уколико се лек примењује на лице трајање лечења треба да буде ограничено на најдуже 5 дана. [...] Максимална недељна доза не сме да буде већа од 60 г.

Деца: Примена лека код деце треба да се ограничи на период од 5 дана. Дуготрајну, континуирану примену лека треба избегавати код свих пацијената без обзира на узраст. [...]

[...] Ако користите маст чешће него што би требало, или је наносите на велике површине ваше коже, то може да утиче на стање неких ваших хормона. Код деце може утицати на раст и развој. [...]

Прилог 5 - Ненад Гладић: „Гастрономад” (одломак). У питању је текст који је на граници између књижевно-уметничког и популарног као врсте научног стила (путопис и кувар), одломак из истоимене књиге. Књига је писана по телевизијском серијалу, што пружа студентима могућност за разумевање телевизијских садржаја. Текст се уклапа у тему Гастрономија (1. лекција), садржи и елементе који одговарају теми Путоваға (9. лекција). Пошто један део текста чини рецепт, студенти се оспособљавају за разумевање упутстава.

\section{Велико северноамеричко краљевство разноликости - Америка и Канада}

Разлог због којег ово моје путешествије почиње у Северној Америци једноставан је.

Моје прво озбиљно гастрономадско искуство започето је управо тамо.

Наиме, тамо сам се у Сан Франциску 1991. године први пут укрцао на брод Crystal Harmony (Кристална хармонија). Први рецепт који сам научио био је рецепт за овај морепловачки хлеб од седам кора. Нема га ни у једном кувару, па га неће бити ни у овом. То је прича за неку другу прилику.

За неупућене, ова дестинација може да се учини кулинарски неинтересантном. ВЕЛИКА заблуда! [...] 
[...] Начин припреме:

Размутити квасац у води са додатком $1 / 2$ кашичице соли и шећера па оставити 15 минута да кисне. У брашно додати преосталу со, улити квасац и уље и замесити тесто. Евентуално, при мешењу теста додавати још брашна или воде, док маса не постане компактна, мекана на додир и не почне да се одваја од зидова посуде. Умешено тесто прекрити крпом и оставити 30 минута на топлом да нарасте. $[\ldots]^{20}$

Прилог 6 - чланак из дневног листа „Блиц"21. Текст припада журналистичком стилу. Уклапа се у тему везану за посао (8. лекција). Студенти се читањем овог текста додатно оспособљавају за разумевање чланака и извештаја о савременим проблемима друштва у којима се износи посебно гледиште. Студентима се, такође, може пружити прилика за прављење резимеа новинског текста, као и за коришћење обавештења, идеја и размишљања из текстова ради информисања и вођења расправе (предвиђено за Б2+ ниво). Читањем текста богати се и вокабулар, студенти су у прилици да усвоје речи које се односе на посао и запошљавање као нпр. преквалификовати се, волонтирати, аплициирати.

На Сајам запошљавања дошле су и три жене са факултетским дипломама које годинама безуспешно покушавају да нађу посао и преко Националне службе за запошљавање.

Једина понуда коју су за све те године добиле је - да се преквалификују у пица-мајсторе.

- Ја сам дипломирани молекуларни биолог и физиолог. Веома дуго тражим посао. До сада сам само волонтирала, и то у Институту за кукуруз. И то је то. Знате ли како је тешко живети без прихода? Послала сам око 100 пријава за посао. Не само да ме нико није запослио већ ме нико никада није ни позвао на разговор. Ето, једино су ми у Националној служби за запошљавање предложили да се преквалификујем у пица-мајстора. Очајна сам, па ћу на крају пристати и на то - рекла је за „Блиц” Невенка Н.

Дугачки редови незапослених испред Дома омладине. Сви би само посао.

- Дипломирала сам кинески језик на Филолошком факултету и тражим посао већ годинама. Досад сам радила само хонорарно, непријављена. Имам 35 година, а морала сам да позајмим новац да дођем на сајам, јер нисам имала чак ни за аутобуску карту. Једино да постанем пица-мајстор,

${ }^{20}$ Аутентичан изглед страница са путописним текстом и рецептом налази се у мастерском раду. За потребе овог чланка, као илустрација, одабрани су само поједини сегменти.

${ }^{21}$ ЕВО ЗАШТО ОБРАЗОВАНИ ЉУДИ БЕЖЕ ИЗ СРБИЈЕ: Бачите дипломе, траже се пищамајстори (аутор: Ана Ђокић, датум: 15.5.2015) 
јер су ми то понудили у Националној служби за запошљавање. Мораћу да се преквалификујем - каже С. П.

Посао тражи и мастер технологије Н. М. али и њој је понуђено да постане пица-мајстор. ${ }^{22}$

Прилог 7 - чланак из „Вечерњих новости"23. Текст припада журналистичком стилу, али се по форми и садржају разликује од претходног. Уклапа се у тему Путовања (9. лекција). Што се садржаја тиче, у питању су савети, упутства. Студентима се пружа прилика за коришћење обавештења из специјализованих текстова ради информисања (предвиђено за Б2+ ниво). Текст садржи корисне информације које се могу применити у свакодневним ситуацијама.

[...] Међутим, рецепционери, који важе за срце хотела и одличне психологе, једногласни су и када је у питању листа шта никада не желе да чују.

1. Никада не треба рећи: Јуче сам разговарао са неком девојком. Гост би требало да запамти име особе којој се жали уколико му је важно да реши проблем.

2. Не треба одмах и за ситнице тражити шефа и прекидати га у послу, јер се они укључују само када је проблем нерешив.

3. Гост никада не сме да каже да је важна или богата личност, јер су сви гости подједнако важни.

4. Треба се жалити на конкретан проблем уз тачно објашњење.

5. Рецепционере, собарице и конобаре треба гледати у очи, јер ко гледа у под нешто крије. 24

\section{5. ЗАКЉУЧАК}

На основу анализе постојећих текстова у уџбенику, примећује се да, поред компетенција везаних за ниво Б2, студент може стећи и компетенције предвиђене за ниво Б2+: разумевање специјализованих публикација уз повремено коришћење речника ради провере разумевања, прављење резимеа различитих типова текстова, коментарисање, расправљање, изношење критике.

${ }^{22}$ Комплетан чланак налази се у мастерском раду, за потребе овог рада издвојен је само један сегмент.

${ }^{23}$ Шта не треба да радите у хотелу (аутор: А. К, датум: 22.5.2015)

${ }^{24}$ Комплетан чланак налази се у мастерском раду, за потребе овог рада издвојен је само један сегмент. 
Што се тиче аутентичности, од осам посматраних текстова, преко $50 \%$ су конструисани текстови (У једном новосадском ресторану, Медицина или надрилекари, У продавници спортске опреме, Поздрав са Копаоника, као и део текста $У$ потрази за послом) - укупно четири цела и велики део петог текста. Појављују се два аутентична (Добро дрво и Коса + оглас у оквиру $y$ потрази за послом) и један адаптиран текст (Криви $u$ организатори и навијачи). Што се форме казивања тиче, највише је текстова у форми дијалога - 50\% (У једном новосадском ресторану, Медичина и надрилекари, У продавници спортске опреме, У потрази за послом), али је присутна разноликост јер се јављају и текстови у облику новинског извештаја (Криви и организатори и навијачи), писма/разгледнице (Поздрав ca Копаоника), прозног текста (Добро дрво) и одреднице из енциклопедије или научно-популарног часописа (Кoca).

Оно што у посматраном уџбенику евентуално недостаје јесу могућности оспособљавања за: читање и разумевање упутства (разумевање дужих и сложених упутстава, укључујући и детаље који се односе на услове одржавања и примене); разумевање информативних емисија и телевизијских серија, документарних филмова, интервјуа, расправа, филмова (српски превод, записи); прављење резимеа новинских текстова, разговора, документарних филмова и резимеа неког филма или позоришне представе произвођење текстова. Студентима се, такође, не пружа прилика за коришћење обавештења, идеја и размишљања из веома стручних текстова у свом подручју приликом читања ради информисања и вођења расправе (предвиђено за Б2+ ниво). Неки од наведених недостатака могу се отклонити уз помоћ предложених аутентичних текстова домаћих аутора којима би се постојећи заменили или допунили.

\section{ЛИТЕРАТУРА}

Анђелковић, С. (2011). “Текстови српских песника и драмских писаца од катедре до сцене", у Српски као страни језик у теорији и пракси. 2, ур. В. Крајишник (Београд: Филолошки факултет): 335-341.

Byrnes, H. (1998). "Teaching reading", in Reading in the beginning and intermediate college foreign language class. Modules for the profesional preparation of teaching assistants in foreign languages. Pristupljeno 21. 3. 2017.

URL: <http://www.nclrc.org/essentials/reading/reindex.htm>.

Ђоровић, Д. (2011). "Вештине читања и развијања вокабулара за специфичне потребе у настави језика струке на универзитетском нивоу”. Теме 35/3: 819-836. Приступљено 20. 3. 2017. URL: <http://teme.junis.ni.ac.rs/teme32011/teme\%203-2011-07.pdf>. 
Marković, J. (2005). "Ekstenzivno čitanje u nastavi stranih jezika”. Radovi Filozofskog fakulteta 6-7: 491-497. Pristupljeno 23. 3. 2017.

URL: <http://www.filozof.org/pdf\%20format/jelena\%20markovic\%2028.pdf>.

Миловановић, А. (2007). “Савремене методе и нови приступи у учењу српског као страног језика”. Српски као страни језик у теорији и пракси. 1, ур. М. Дешић (Београд: Филолошки факултет): 91-98.

Scrivener, J. (2005). Learning Teaching - A guidebook for English language teachers Second Edition. Great Britain: Macmillan Publishers Limited. Pristupljeno 20. 3. 2017. URL: <https://archive.org/stream/Learning-Teaching/Learning-Teachingby-James-Scrivener\#page/n13/mode/2up >.

Ur, P. (1997). Discussion that Work: Task-centered fluency practice. Cambridge: University Press.

Zajednički evropski okvir za žive jezike: učenje, nastava, ocjenjivanje (2003). Podgorica: Ministarstvo prosvjete.

\section{ИЗВОРИ:}

Alanović, M. i dr. (2007). Naučimo srpski (Let's learn Serbian) 2. Novi Sad: Dnevnik novine i časopisi.

Blic - online. Pristupljeno 10. 6. 2015.

URL:<http://www.blic.rs/Vesti/Ekonomija/559147/EVO-ZASTO-BRAZOVANI-

BEZE- IZ-SRBIJE-Bacite-diplome-traze-se-picamajstori>.

Dučić, J. (2005). Blago cara Radovana; Jutra sa Leutara. Novi Sad: Ljubitelji knjige.

Gladić, N. (2011). Gastronomad. Beograd: Laguna. Pristupljeno 10. 6. 2015.

URL: <http://www.laguna.rs/n1483_knjiga_gastronomad_laguna.html>.

Пипер, П., Драгићевић Р., Стефановић М. (2005). Асоиијативни речник српскога језика. Београд: Београдска књига: Службени лист СЦГ: Филолошки факултет.

Речник српскохрватског књижевног и народног језика. Књ. 10 (1978). Београд: Српска академија наука и уметности: Институт за српскохрватски језик.

Uputstvo za lek Diprosalic (poslednji put odobreno: avgust, 2012). Belgija: ScheringPlough Labo N. V. (proizvođač); Beograd: Schering-Plough Central East AG (predstavništvo).

Вечерње новости - онлајн. Приступљено 10. 6. 2015. URL: <http://www.novosti.rs/\%D0\%B2\%D0\%B5\%D1\%81\%D1\%82\%D0\%B8/\%D1\% 82\%D1\%83\%D1\%80\%D0\%B8\%D0\%B7\%D0\%B0\%D0\%BC.523.html:549158Sta-ne-treba-da-radite-u-hotelu>. 
Jelena Perišić

\title{
AUTHENTICITY OF TEXTS USED IN TEACHING SERBIAN AS A FOREIGN LANGUAGE AT HIGHER LEVELS OF LEARNING
}

\begin{abstract}
Summary
A very important element of every foreign language course is the textbook and its inevitable part, in addition to the most diverse types of assignments, are texts. The question is to what extent these texts should be authentic, as well as if it is necessary for them to differ in terms of category or type to which they belong. The aim of this paper is to check the validity of chosen texts according to the parameter of authenticity, specifically the domain of functionality and style. In accordance with the set goal, the current state of the textbook for Serbian as a foreign language Let's learn Serbian 2 will be investigated, as well as the requirements set by the relevant literature and the Common European Framework of Reference for Languages, based on which a corpus analysis will be conducted and dominant features and potential deficiencies will be registered. At the end, corrections and additions of the texts in the observed textbook will be suggested. On the basis of the analysis of texts in the textbook it can be concluded that students can acquire competences both for the B2 and B2+ levels, which implies understanding specialized publications with an occasional use of dictionaries. As for authenticity, around $50 \%$ of the texts are constructed, whereas there are two authentic and one adapted text. When form is concerned, the majority of texts comprise dialogues, but there are also newspaper reports, letters, postcards, prose and encyclopaedic entries.
\end{abstract}

Keywords: Serbian as foreign language, type of text, authenticity, level B2.

Primljeno: 29.4.2017.

Prihvaćeno: 27.7.2017. 